\title{
Sendikaların Sosyal Medya Kullanımına İşçilerin Bakışı: Bursa ve Kırklareli Örneği
}

\section{The Perspectives of Workers on Social Media Use of Trade Unions: The Case of Bursa and Kırklareli}

Hüseyin Sevgi ${ }^{1}$ (), Aysen Tokol ${ }^{2}$ (1)

Öz

Bilgisayar ve internet teknolojilerinde hızla gerçekleşen dönüşüm gerek günlük yaşamı gerekse çalışma yaşamını derinden etkilemektedir. Taşınabilir akıllı cihazların yaygınlaşması ve kablosuz-mobil internet ağlarının genişlemesiyle birlikte, internete erişim daha önce hiç olmadığı kadar kolay ve hızlı gerçekleşmeye başlamıştır. Bu paralelde tüm demografik, siyasi ve sosyo-ekonomik farklılıklarından bağımsız olarak işçiler de hızla birer internet kullanıcısına dönüşmüştür. Web 2.0 ile birlikte bilgisayar ve internetteki iletişimin doğası farklılaşarak, çift yönlü etkileşimin önemli olduğu bir süreç ortaya çıkmıştır. Bu süreç, sosyal medya platformlarını popülerleştirmiş, internet kullanıcılarını daha önce hiç olmadığı kadar aktif bir duruma getirmiştir. Bireyler sosyal medya sayesinde doğrudan içerik üretebilme ve başka kişilerin ürettiği içeriklerle etkileşime girme şansı yakalamışlardır. Bu bağlamda, sendikaların internet ve sosyal medya teknolojilerine nasıl yaklaşacağı ve bu teknolojilerden nasıl etkileneceği tartş̧ma konusu olmuştur. Bu çalışmada sendikalar ve sosyal medya arasındaki ilişki hem kavramsal olarak hem de güncel örneklerle incelenmiştir. Ayrıca Bursa ve Kırklareli'nde sendikalı işçilerle yapılan derinlemesine görüşmelerle sendikaların sosyal medya kullanımına dair iş̧̧ilerin bakış açısı değerlendirilmiştir.

Anahtar Kelimeler

Sendika, Sosyal Medya, İnternet, Bursa, Kırklareli

1 Sorumlu Yazar: Hüseyin Sevgi (Dr.), Kırklareli Üniversitesi, İktisat Fakültesi, Çalışma Ekonomisi ve Endüstri. İlişkileri Anabilim Dalı, Kırklareli, Türkiye. E-posta: hsevgi@gmail.com Orcid: 0000-0003-0295-0723

2 Aysen Tokol (Prof. Dr.), Uludağ Üniversitesi, İktisat Fakültesi, Çalışma Ekonomisi ve Endüstri. İlişkileri Bölümü, Bursa, Türkiye. E-posta: aysentokol@yahoo.com Orcid: 0000-0003-1266-3795

Atıf: Sevgi, H. ve Tokol, A. (2020). Sendikaların sosyal medya kullanımına işçilerin bakışı: Bursa ve Kırklareli örneği. Sosyal Siyaset Konferansları Dergisi, 79, 299-328. https://doi.org/10.26650/jspc.2020.79.0099 


\begin{abstract}
The rapid transformation of computer and internet technologies has affected both daily life and working life profoundly. The widespread use of mobile smart devices and the expansion of mobile networks have made access to the internet easier and faster than ever before. Regardless of demographic, political, and socio-economic differences, workers have promptly transformed into internet users. Owing to Web 2.0, the nature of digital communication has changed. New forms of interaction have emerged in this process, which has popularized social media platforms, allowing internet users to be unprecedentedly active. Users can produce their own content and interact with other people's content on social media. In this context, how unions approach and are affected by the internet and social media technologies has been a research topic. In this study, the relationship between unions and social media was examined both conceptually and with current examples. In addition, in-depth interviews with unionized workers in Bursa and Kırklareli evaluated the workers's perspective regarding the social media use of the unions.
\end{abstract}

\title{
Keywords
}

Trade Unions, Social Media, Internet, Bursa, Kırklareli 


\section{Extended Summary}

Social media, one of the new information and communication technologies, has become an indispensable part of our daily life. Social media platforms, used by millions of people every day, are more than just communication tools. In this respect, social media has become a new place where social relations, culture, art, and ideology are reproduced. Accordingly, the internet and social media have led to radical changes in the communication, organization, and forms of action by activists involved in social movements. These changes in social movements caused by social media have inevitably affected labor unions and workers.

First, the idea that the internet and social media affect trade union organizations negatively and create an obstacle to unions has been discussed in the literature. However, the impact of new information and communication technologies in daily life has increased rapidly. Consequently, unions cannot abstain from new communication technologies. Thus, the notion that these technologies will provide renewal to unions and that unions can benefit from new communication technologies is increasingly accepted.

A critical way for unions to benefit from new communication technologies is active user participation on social media. Active user participation, an essential feature of social media with Web 2.0, refers to a double-sided interaction. Owing to Web 2.0, internet users are not only viewers on social media. They are in an active position to produce media content directly, consume it, and interfere with existing content. This active position of internet users is called a "prosumer." More precisely, the prosumer is a person who consumes and produces media content. The concept of the prosumer has become one of the main features of social media after Web 2.0. At present, almost all social media users have transformed into prosumers by producing and consuming social media content. The role of the prosumers is that they provide unions with a significant opportunity to interact with workers. Labor unions can reach workers faster and easier than ever before using social media. Moreover, several labor union activities can be conducted more easily on social media.

The integration of labor unions on social media has accelerated in recent years. However, many national labor unions are slower in terms of social media integration than international unions. For example, the International Trade 
Union Confederation and the European Trade Union Confederation actively use social media in almost all union activities. They use social media platforms particularly for international solidarity, international propaganda, and digital campaigns. Some national labor unions have also started to use social media effectively after understanding its importance. For example, labor unions in countries such as Spain, France, Australia, Germany, England, Netherlands, and Canada use social media more effectively and in more areas than before. Importantly, the use of social media by national unions did not emerge spontaneously. The fact that workers have become active in social media is one of the most important factors that propelled labor unions to use social media. For example, workers have started to carry out some activities by establishing groups on social media.

Because of Web 2.0 it is not only in their own control that unions can be active on social media. Therefore, it is essential to examine the workers' perception of the union on social media. Put differently, the union can define itself as an active organization on social media, but it is critical how workers define the union on social media. Regular sharing on social media does not show that a union actively uses social media. The important thing is not to share too many posts, but to receive as much positive interaction from workers as possible. The success of a union on social media is directly proportional to the extent to which it responds to the workers' expectations. Therefore, workers' perceptions of the use of social media by the unions are critical.

In this context, the concept of social media, emergence of social media, relationship of social media with traditional mass media and its historical development, and how and for what purpose social media is used by national and international unions are examined in this study. Next, the data obtained through in-depth interviews held in Bursa and Kırklareli provinces with workers who are members of different unions and have different demographic features are evaluated. Thus, the aim is to determine how unions perceive social media usage by workers. 


\section{Sendikaların Sosyal Medya Kullanımına İşçilerin Bakışı: Bursa ve Kırklareli Örneği}

\section{Giriş}

Bilgi ve iletişim teknolojileri tüm ekonomik ve endüstriyel alanı yeniden şekillendirmektedir. Bu teknolojilerin birçok alanda geleneksel yapıları dönüştürmesi artık bir tartışma konusu olmaktan çıkmış, çağımızın bir gerçeği haline gelmiştir. $\mathrm{Bu}$ bağlamda yeni bilgi ve iletişim teknolojilerinden biri olan sosyal medya, her gün milyonlarca kişi tarafından kullanılan ağ olarak günlük yaşamımızın vazgeçilmez bir parçası olmuştur. Başlangıçta internet ve sosyal medya geleneksel medya araçlarında (televizyon, gazete, radyo vb.) temsil edilmeyen toplumsal hareketlere alternatif bir iletişim kanalı sağlamış ve bu hareketleri görünür kılmıştır. Ayrica internet ve sosyal medya toplumsal hareketlerde yer alan aktivistlerin iletişiminde, örgütlenmesinde ve eylem biçimlerinde köklü değişikliklere yol açmıştır. Sosyal medyanın toplumsal hareketlerde meydana getirdiği bu değişiklikler, kaçınılmaz olarak sendikalar ve işçiler için de söz konusu olmuştur.

Yeni bilgi ve iletişim teknolojilerinin sendikalara ve işçi sınıfına etkisinin nasıl ve ne derece olacağ tartışmaları görece gecikmeli olmuştur. Başlangıçta internetin sendikal örgütlenmeyi olumsuz etkileyeceği ve sendikalar önünde bir engel yaratacağı düşüncesi ön plana çıkmıştır. Ancak yeni bilgi ve iletişim teknolojilerinin günlük yaşamdaki etkisi arttıkça; bu teknolojilerin sendikalara yenilenme sağlayacağı, dahası ulusal ve uluslararası düzeyde iletişim sistemlerindeki açıkları kapatacağı, işçi sınıfının kendi içindeki diyaloğun önünü açacağı ve sonuç olarak sendikalar için bu yeni teknolojilerin faydalı olacağı düşüncesi literatürde kabul görmeye başlamıştır.

Bu doğrultuda yeni bilgi ve iletişim teknolojileri özellikle ABD, İspanya, Fransa, Avustralya, Almanya, İngiltere, Japonya, Hollanda, Kanada gibi gelişmiş ülkelerdeki sendikalar ile uluslararası sendikalar tarafından daha etkin ve daha geniş alanda kullanılmaya başlanmıştır. Buna karşılık özellikle gelişmekte olan ülkelerde halen sendikaların yeni bilgi ve iletişim teknolojileri kullanımı oldukça sınırlı düzeydedir. Türkiye'de de sendikalara göre değişmekle birlikte, sendikaların internet ve sosyal medya kullanımının oldukça sınırlı düzeyde kaldığ 1 görülmektedir. Ancak üye sayıları, ekonomik ve siyasi etkinlikleri tüm dünyada giderek azalan sendikaların geleceği açısından internet ve sosyal medya kullanımı son derece büyük önem taşımaktadır. 
Sosyal medyanın temel özelliklerinden olan anlık geribildirim ve karşılıklı etkileşim sayesinde sendikaların birçok faaliyetinde sosyal medyayı kullanması çok daha kolay olmaktadır. Diğer yandan sosyal medyanın maliyet açısından da geleneksel iletişim araçlarına kıyasla daha ucuz olması sendikalar için bir avantaj oluşturmaktadır. Dolayısıyla sosyal medyanın sendikalar tarafından kullanılması hem maliyet açısından hem de sosyal medya kullanan milyonlarca kişiye kolay ulaşabilmesi açısından oldukça önemlidir.

Bu paralelde, çalışmada ilk olarak sosyal medya kavramı, sosyal medyanın ortaya çıkışı, sosyal medyanın geleneksel kitle iletişim araçlarıyla ilişkisi ve tarihsel gelişimi ele alınacak, sosyal medyanın ulusal ve uluslararası sendikal örgütler tarafından nasıl ve hangi amaçla kullanıldığı güncel örneklerle incelenecektir. Daha sonra Bursa ve Kırklareli illerinde farklı demografik özelliklere sahip ve farklı sendikalara üye işçilerle yapılan derinlemesine görüşmeler sonucunda elde edilen veriler değerlendirilerek, sendikaların sosyal medya kullanımının işçiler tarafından nasıl algıladığı tespit edilmeye çalışılacaktır.

\section{Geleneksel Kitle İletişim Araçlarından Sosyal Medyaya Dönüşüm}

Geleneksel kitle iletişiminin gelişimi, iletişim teknolojisindeki ilerlemelere paralel biçimde ortaya çıkmıştır. Gazete, dergi, poster, radyo vb. yayın organları ile 1. Dünya Savaşı sırasında ciddi bir manipülasyon aracı haline gelen geleneksel kitle iletişimi, 2. Dünya Savaşı'nda da bu misyonunu sürdürmüştür. Teknolojik gelişmelerle birlikte televizyonun kitleselleşmesi, televizyonu da geleneksel kitle iletişiminin bir parçası haline getirmiştir (Lasswell, 1938, s. 215-216).

Geleneksel kitle iletişimin en önemli ayırt edici özelliği "iletişimin” tek yönlü olmasıdır. İletişim sürecini başlatan mesaj kaynağı ile mesajın ulaştığı kitle arasında karşılıklı bir etkileşim bulunmamaktadır. Bu nedenle geleneksel kitle iletişiminde geribildirim her zaman anlık ve hızlı gerçekleşmemektedir. Bilgi ve iletişim teknolojilerinin hızla gelişmesi, iletişim araçlarını derinden etkileyerek kitle iletişiminin doğasını zamanla değiştirmeye başlamıştır. 1990'ların sonuna doğru bilgisayar ve internet kullanımının yaygınlaşmasıyla birlikte, uzun zamandır kitle iletişimi için kullanılan geleneksel araçlara (gazete, dergi, radyo, televizyon vb.) farklı bir alternatif ortaya çıkmaya başlamıştır. Bilgisayar ve internetin gerek günlük hayata gerekse çalışma yaşamına dâhil olması bilgi ve iletişim teknolojileri sayesinde, tıpkı kitle iletişiminde olduğu gibi, geniş kitlere ulaşma imkânı 
vermiştir. İnternetin yoğun olarak kullanılmaya başlandığ 1 ilk dönemde internetteki iletişimin yapısal gelişimi, geleneksel iletişime benzer şekilde gelişmiştir. A $\breve{g}$ ortamındaki bilgiler geleneksel iletişim araçlarına benzer biçimde bir kişi veya bir merkez tarafından oluşturup internet ağına sunulmuştur. Bu dönemde, günümüzde olduğu gibi internet kullanıcıların ağdaki enformasyon ve içeriklere müdahalesi mümkün olmamıştır. İnternetteki iletişimin bu aşaması WEB 1.0 olarak kavramsallaştırılmıştır (McQuail, 2009, s. 16).

WEB 1.0'da bilgi oluşturma ve dağıtma, tek bir yerden veya merkezden gerçekleşmektedir. İçerikler genel olarak belirli kişi veya kurumlar aracılığı ile oluşturularak, kitle iletişime benzer biçimde tek yönlü olarak ağ ortamına sunulmaktadır. İnternet kullanıcılarının mevcut içerikle ilgili herhangi bir katkısı veya bu içeriklere bir müdahalesi söz konusu değildir. WEB 1.0 internetteki iletişimin karşılıklı etkileşime izin vermediği bir yapıyı ifade etmektedir (Fuchs, 2016, s. 49-50).

Bilgi ve iletişim teknolojilerinin hızla gelişmesi ve internetin giderek günlük yaşamın bir parçası haline gelmesiyle, WEB 1.0 özelinde bilgisayar ve internetin sendikalara ve işçi sınıfına nasıl bir etkisi olacağı tartışılmaya başlanmıştır. Başlangıçta yeni teknolojilerin sendikal faaliyetleri olumsuz etkileyeceği fikri ortaya atılmış bunun sonucunda sendikalar bilgi ve iletişim teknolojilerine mesafeli yaklaşmışlardır (Lee, 2008). Zamanla internetin yaygın olarak kullanılmaya başlanması ve kullanıcı sayısını hızla artmasıyla, internetin sendikalar için bir firsat olabileceği düşüncesi ortaya çıkmıştır. Bu bağlamda, bilgisayar ve internet teknolojilerinin sendikalar için uzun vadede ciddi bir fırsat olduğu ve özellikle iletişim alanında sendikaların birçok açığını kapatarak, sendikal faaliyetlerin önünü açabileceği düşüncesi literatürde daha fazla kabul görmeye başlamıştır (Lucio, 2003, s. 336).

Bilgi ve iletişism teknolojilerinin sendikaların henüz gündemini meşgul etmediği 1990'lardan önce sendikalar geleneksel kitle iletişim araçlarını gerek propaganda ve örgütlenme faaliyetlerinde gerekse diğer birçok sendikal faaliyette kullanmışlardır. Örneğin 1990'lı yıllara kadar sendikalar özellikle çıkardıkları dergi ve gazetelerle geniş kitlelere ulaşmışlardır (Krasenkiene, Kazokiene ve Susniene, 2014, s. 3-5).

Sendikalar 2000'li yılların başlarından itibaren WEB 1.0'a ruhuna uygun internet sayfaları ve e-posta listeleri gibi araçlarla internet teknolojilerini 
kullanmaya başlamışlardır (Selamoğlu ve Özsoy, 2008, s. 33-34). Bu bağlamda sendikaların yeni teknolojilere uyumu uluslararası sendikalarda daha hılı gerçekleşmiştir. Örneğin, Avrupa Sendikalar Konfederasyonu (ETUC), resmi internet sayfası olan https://www.etuc.org/ 'un ilk kaydını 1997 yılında yaparak internet çalışmalarına başlamıştır. Benzer biçimde Uluslararası Sendikalar Konfederasyonu (ITUC) henüz kuruluş kongresini (1-3 Kasım 2006) dahi yapmadan önce 23 Ekim 2006'da resmi internet sayfası olan https://www. ituc-csi.org/ 'un kaydını yaptırmıştır (ICANN, 2020).

2000'li yıllardan sonra bilgi ve iletişim teknolojilerindeki hızlı değişim, bilgisayar ve internet tabanlı iletişimi de temelden dönüştürerek günümüze kadar gelmiştir. 1990'ların sonuna doğru çoğunlukla geleneksel kitle iletişimin özelliklerini yansıtan ve WEB 1.0 olarak kavramsallaştırılan bilgisayar ve internet üzerinden iletişim 2005 yılında sonra baştan aşağı değişerek yeni bir form kazanmıştır. 2005 yılından sonra internet aracılığı ile gerçekleşen iletişimin geleneksel kitle iletişiminden farklı olması gerektiği düşüncesi yaygınlık kazanmıştır. Bu düşünce zamanla, internet kullanıcıların aktif katılımıyla ağdaki içeriklere müdahale edebilmesinin önünü açmıştır. Böylece bilgi ve iletişim teknolojilerinde WEB 2.0 olarak bilinen yeni bir dönem başlamıştır. WEB 2.0 günümüzde milyonlarca kişinin kullandığı sosyal medya platformlarının temelini oluşturmaktadır (O’Reilly, 2005).

WEB 2.0 ile internetteki iletişimin yapısı değişerek, geleneksel kitle iletişiminden giderek uzaklaşılmıştır. Günümüzde sosyal medya olarak adlandırılan platformlarının tamamı WEB 2.0 ile doğan "aktif kullanıcı katılımı" düşüncesinin bir sonucudur. WEB 2.0; internet kullanıcılarının doğrudan içerik üretebildiği veya mevcut içeriklere müdahale edebildiği, karş1lıklı etkileşimin üst düzeyde olduğu aktif katılımlı bir ağ ortamı yaratmıştır. Bu bağlamda WEB 2.0'ın en belirleyici özelliği aktif kullanıcıların ağın bir parçası haline gelmesidir. İnternet kullanıcıları pasif tüketici olmaktan ziyade, kendi içeriklerini üreten, bu içerikleri başkalarıyla paylaşan ve mevcut içerikleri tüketen yüksek etkileşimli bir pozisyondadır (Van Dijck, 2013, s. 11; Gauntlett, 2011, s. 4).

Sosyal medya platformları başlarda sadece "eğlence" aracı olarak görülmüş, sendikalar ve birçok örgüt tarafından ciddiye alınmamıştır. Ancak hızla artan kullanıcı sayısı sosyal medyanın geniş kitlere ulaşmada bir araç olarak kullanılabileceği gerçeğini ortaya çıkarmıştır. Böylece bu platformlar, eğlence ağı olmaktan çıkarak aynı zamanda mikro ve makro iktidar merkezlerine karşı 
politik bir zemine kavuşmaya başlamıştır. Bu durumun ortaya çıkmasında; geleneksel kitle iletişim araçlarına ulaşmanın çok daha zor/pahalı olması ve geleneksel kitle iletişim araçlarının göre sosyal medyanın daha az denetime tabi olması önemli rol oynamıştır (Fuchs, 2015, s. 11-12).

Sosyal medyanın politik örgütlenme aracı olarak kullanılmaya başlanması 2011 yılında doruğa ulaşmıştır. Bu bağlamda, önce Arap ülkelerinde daha sonra ise Avrupa'da ve ABD'de toplumsal olaylar sosyal medyanın etkisiyle ulusal ve uluslararası düzeyde daha görünür hale gelmişlerdir. Sosyal medyadan örgütlenen milyonlarca kişi politik temelli taleplerle çok ciddi protestolar başlatmıştır. Bu protestolardan sonra sosyal medyanın sadece bir "eğlence" aracı olmadığı, kitleler tarafından örgütleme aracı/alanı olarak da kullanılabileceği ortaya çıkmıştır. Toplumsal muhalefetin sosyal medyayı başarılı biçimde kullanması sendikaların da dikkatini çekmiştir. Bu tarihten sonra sendikalar da sosyal medyayı kendileri için bir örgütlenme aracı/alanı kullanabileceklerini fark etmişlerdir. Böylece sendikalar sosyal medyaya olan ilgilerini artırarak bu alanda da çalışmalara başlamışlardır (Gerbaudo, 2012, 6-7; Sevgi, 2019, s. 64).

Sosyal medyanın bir örgütlenme aracı/alanı olarak kullanılabileceğinin anlaşılmasından sonra, birçok örgüt gibi sendikalar da yavaş yavaş sosyal medya kullanmaya, bilgi ve iletişim teknolojilerine karşı olan "mesafeli” tavırları zamanla değişmeye başlamışlardır. Kuşkusuz bunun nedenleri arasında, taşınabilir akıllı cihaz kullanımının artması, kablosuz ve mobil internet ağlarının genişlemesiyle birlikte sosyal medyanın işçiler arasında da hızla yaygınlaşmasının payı oldukça fazla olmuştur (Parry, 2013).

Sosyal medya doğası gereği aktif kullanıcı katılımını öngördügünden, sendikaların kullandığı geleneksel iletişim araçlarından çok farklı olan sosyal medyanın nasıl ve hangi sendikal faaliyetlerde kullanılabileceği tartışılmaya başlanmıştır. Başlangıçta sendikaların sosyal medyayı sadece bir iletişìm aracı olarak (işçilere mesaj gönderme, duyuru yayınlama vb.) kullanması söz konusu olmuşsa da zamanla neredeyse tüm sendikal faaliyetlerde sosyal medyanın kullanılabileceği ortaya çıkmıştır (Almagor, 2011, s. 47).

\section{Sendikaların Sosyal Medya Kullanımı}

Bilgi ve iletişim teknolojilerindeki ilerlemeyle birlikte sosyal medya olanakları da hızla artmıştır. Bu bağlamda, günümüzde sosyal medyanın 
sunduğu imkânlarla, örgütlenme, iletişim, eğitim, toplu pazarlık, grev ve eylemler gibi temel sendikal faaliyetlerin sosyal medya aracılığg ile yapılabildiği görülmektedir. Bunların yanında sosyal medyanın sendikal katılım, sendikal şeffaflık, sendika içi demokrasinin geliştirilmesi, sendikal dayanışma, kamuoyu oluşturulması ve toplumsal meşruiyetin sağlanması gibi hayati konularda da güçlü bir araç olduğu kabul edilmektedir (Panagiotopoulos ve Barnett, 2015, s. 511-512; Guppta, 2016; Gerbaudo, 2013, s. 6; Y1lmaz Sert, 2015: 115; Atabek \& Yücesan Özdemir \& Yüce, 2006).

Sendikalar açısından çok farklı amaçlarla kullanma potansiyeline sahip olan sosyal medya ve yeni iletişim teknolojileri özellikle sendikaların örgütlenme ve propaganda çalışmalarında önem kazanmaktadır. Sosyal medyanın sunduğu hızlı, anlık ve ucuz iletişim sendikalar için işçilere daha kolay yoldan ulaşma imkânı vermektedir. Sosyal medya sendikalara üyeleriyle iletişim kurma, duyurular yapma ve bilgi vermek için de oldukça uygun bir ortam sunmaktadır. Akıllı cihazlar sayesinde günün her saati sosyal medya ve internete erişim olanağ bulunan işçilere ulaşmak daha önce hiç olmadığg kadar kolay olmaktadır. Sosyal medyanın bu iletişim misyonu, sendika üyesi işçiler arasında da dayanışmayı ve iletişimi artırmaktadır. Ortak ağlar içinde yer alan sendika üyesi işçiler birbirleriyle çok daha rahat iletişim kurabilmektedir (Tokol, 2019, s. 165-166).

Sendika içi demokrasinin geliştirilmesinde de sosyal medya ve yeni iletişim teknolojileri sendikalar tarafından bir araç olarak kullanılabilmektedir. Sosyal medya sayesinde, geleneksel iletişim araçları ile sesini duyurmakta zorlanan dezavantajlı gruplar (kadınlar, engelliler, azınlıklar, eşcinseller vb.) sendikalara daha rahat ulaşabilmekte, toplumsal görünürlüklerini artırabilmektedir. Dolayısıyla sendikaların bu gruplara karşı sessiz kalması da zamanla imkânsız hale gelmektedir (Colgan ve Ledwith, 2003, s. 156).

Toplu pazarlık, grev ve eylemler gibi temel sendikal faaliyetlerde de sosyal medya bir araç olarak kullanılabilmektedir. Gerekli teknik altyapı ve yasal düzenlemeler yapıldıktan sonra internet üzerinden katılımcı e-toplu pazarlık veya grev öncesi e-oylama gibi uygulamalarla temel sendikal faaliyetlerin sosyal medya üzerinden yürütülmesi mümkün olmaktadır. Örneğin Hollanda, İngiltere ve İsveç gibi ülkelerde sendikalar e-oylama yöntemini sıklıkla tercih etmektedir (Regov, Sprenger, Kirov, Thomson ve Nunzio, 2016, s. 219-225). 
Sendikalar grev ve eylemlerde de yeni teknolojilerden faydalanmaktadır. Grev ve eylemlerde yeni teknolojilerin kullanılması genellikle üç aşamada gerçekleşmektedir: Bunlar; grev öncesi, grev esnasında ve grev sonrası şeklinde sıralanabilir. Grev öncesinde, greve desteği ve katılımı artırmak amacıyla işçilere yönelik özel propaganda grupları veya tartışma sayfaları kurarak, işçilerin greve zihinsel olarak hazırlanması için çalışmalar yapılmaktadır. Grev öncesinde çoğunlukla haklı olduğu düşünülen talepler ön plana çıkarılmaktadır. Sosyal medyanın en etkin kullanılacağı aşama grev esnasıdır. Grevin yürütüldüğü bu aşamada sosyal medya çoğunlukla güçlü bir propaganda aracı olarak kullanılmaktadır. Fotoğraf ve videolarla desteklenen propaganda faaliyeti ile greve olan desteğin artırılması amaçlanmaktadır. Grev sonrasında ise, grevin nasıl sonuçlandığına bağlı olarak işçilerden alınacak geribildirimlerde sosyal medya aktif olarak kullanılmaktadır (Nicita ve Rizzolli, 2009, s. 143-144).

Sosyal medyanın sendikal faaliyetler açısından bir diğer kullanım alanını sendikal eğitimler oluşturmaktadır. Sosyal medyanın eğitim faaliyetlerinde kullanılması maliyet ve kolaylığın yanında, zaman ve mekân zorluklarını da ortadan kaldırması bakımından önem taşımaktadır. Sosyal medya platformlarının cep telefonu uygulamaları sayesinde sendikal eğitime ulaşmak günümüzde sadece "an" meselesi haline gelmektedir (Hodder ve Houghton, 2015, s. 176).

Birçok sendikal faaliyette kullanılabilen sosyal medyanın uluslararası sendikalar tarafından görece daha etkin kullanıldığı görülmektedir. Bilgi ve iletişim teknolojilerine çok daha hızlı uyum sağlayan uluslararası sendikalar özellikle 2011 yılından sonra sosyal medyaya ayrı bir önem vermeye başlamışlardır. Bu bağlamda uluslararası sendikalar sosyal medya üzerinden kampanyalar, etkinlikler, çevrimiçi eylemler, boykotlar, propaganda ve örgütlenme gibi birçok çalışma yapmaktadırlar.

Bu bağlamda Uluslararası Sendikalar Konfederasyonu (ITUC) ve Avrupa Sendikalar Konfederasyonu (ETUC) sosyal medyayı en etkin kullanan uluslararası sendikalar arasında yer almaktadır. Hem ITUC hem de ETUC; Twitter, Facebook, Instagram ve Youtube gibi tüm popüler sosyal medya platformlarında aktif faaliyet göstermektedir. Sosyal medya hesaplarından her gün binlerce kullanıcıya ulaşan ITUC ve ETUC özellikle Twitter hesaplarını 
diğer sosyal medya platformlarına görece daha aktif kullanmaktadır1. Sosyal medyayı iletişim, örgütlenme, uluslararası dayanışma ve kamuoyu oluşturma faaliyetlerinde yoğun biçimde kullanan ITUC ve ETUC mevcut kampanyaların tümünü aynı zamanda sosyal medya üzerinden desteklemektedir. Her iki örgüt sosyal medya üzerinden birlikte yürüttükleri kampanyalarla da dikkat çekmeye çalışmaktadırlar. Örneğin, ITUC'un mevcut en güncel çevrimiçi kampanyası \#Timefor8 etiketiyle başlattığ 1 , Birleşmiş Milletler Sürdürülebilir Kalkınma Hedefleri içinde 8. Hedef olan "İnsana Yakışır İş” hedefidir. Bu çevrimiçi kampanya ETUC tarafindan da sahiplenilerek sosyal medyadan desteklenmektedir. Aynı zamanda ulusal sendikalar da \#Timefor8 etiketiyle kampanyaya destek vermektedirler.

Sosyal medyanın etkileşim gücünden yararlanmak isteyen ITUC ve ETUC propaganda ve kamuoyu faaliyetlerini sıklıkla sosyal medya hesapları üzerinden yürütmektedirler. Örneğin, ITUC'un çalışma hayatı ile ilgili sorunların giderilmesi için başlattığı, "Barış ve Demokrasi”, "Ekonomik Denge", "Adil Geçiş" ve "Eşitlik" başlıklı dört temel talebi içeren \#ChangeTheRules kampanyasını sosyal medya üzerinden devam ettirmekte ve ciddi bir propaganda faaliyeti yürütmektedir. Benzer biçimde ETUC da \#GenderPayGap etiketiyle başlattığı ve çalışma hayatında cinsiyetler arasındaki eşitsizliğe dikkat çektiği kampanyasını sosyal medya üzerinden yürütmekte, çoğunlukla Youtube'dan dikkat çekici videolar ile propaganda faaliyeti yapmaktadır.

Güncel gelişmeleri de yakından takip eden ITUC ve ETUC Covid-19'un çalışma hayatında yarattığı olumsuz sonuçların giderilmesine yönelik Twitter ve Facebook'tan paylaşımlarını artırmıştır. \#COVID19 etiketi altında çalışma hayatında hak kayıpları ile ilgili bulguları ve geleceğe yönelik taleplerini etkileyici görsellerle paylaşarak uluslararası kamuoyunun dikkatini çekmeye çalışmaktadır. Covid-19'un yarattığı olağanüstü koşullarda ITUC ve ETUC sosyal medyayı sadece iletişim ve propaganda amacıyla değil aynı zamanda uluslararası sendikal dayanışma sağlamak ve 1 Mayıs etkinliklerini online ortamda yapmak için çalışmalar başlatmışlardır. Bu amaçla; 1 Mayıs

1 Sosyal medyada aktif olmak ile çok fazla takipçiye sahip olmak yanı şeyler değildir. Taipçi sayısının zamanla artması sosyal medyayı etkin ve aktif kullanmanın bir sonucu olabilmektedir. Bununla beraber az takipçiye sahip olmak, bir örgütün sosyal medyada aktif olmasının önünde bir engel değildir. Bu nedenle bir sosyal medya hesabının etkinliğini takipçi sayısına göre kıyaslamak yanıltıcı olabilmektedir. Takipçi sayısı ziyade sosyal medyada oluşturulan ağın yoğunluğu söz konusu hesabın etkinliğini göstermede daha isabetli bir yöntemdir. Bu yoğunluk başta "sosyal ağ analizi” olmak üzere bazı analiz yöntemleriyle tespit edilebilmektedir. 
kutlamalarının Covid-19 nedeniyle çevrimiçi yapılması için \#1MaySolidarity, \#VirtualMayDay etiket kampanyalarına Twitter ve Facebook üzerinden aktif biçimde yürütmüşler ve binlerce kişiye ulaşmayı başarmışlardır.

Sosyal medya ve internet teknolojisine daha yavaş adapte olan ulusal sendikalar, son yıllarda sosyal medya platformlarını daha fazla kullanmaya başlamıştır. Uluslararası sendikalara kıyasla yeterli düzeyde olmasa da ulusal sendikaların hızlı bir gelişim gösterdikleri görülmektedir. Bu konuda ABD, İspanya, Fransa, Avustralya, Almanya, İngiltere, Japonya, Hollanda sendikaları örnek olarak gösterilebilir.

Hollanda Sendikalar Konfederasyonu (FNV) en popüler sosyal medya platformlarının tamamında aktif olarak oldukça başarılı çalışmalar yürütmektedir. FNV; düzenli paylaşımları, hazırladığı etkileyici görsel ve videoları ile sosyal medyadan ciddi bir kitleye ulaşabilmektedir. Örgüt bu sayede kitlesel iletişim, propaganda ve örgütlenme faaliyetlerini sosyal medya üzerinden yürütebilmektedir. Örneğin, ücretlerde alınan vergiler, göçmen işçilerin durumu ve çalışma yaşamında kadın erkek eşitliği için sosyal medyadan propaganda ve örgütlenme faaliyeti yürütmektedir. Son dönemde Covid 19'a karşı işçilerin korunmasına yönelik sosyal medyadan başlatılan \#StopthePandemicAtWork kampanyasına destek veren FNV; ITUC gibi \#VirtualMayDay etiketiyle 1 Mayıs etkinliklerinin online yapılması için destek vermiştir.

Alman Sendikalar Birliği (DGB) ve Fransa İşçi Sendikaları Konfederasyonu (CGT) de tıpkı FNV gibi sosyal medyayı aktif kullanan ulusal sendikalar arasındadır2. Genellikle iletişim ve propaganda faaliyetleri için sosyal medyayı kullanan DGB Twitter'da CGT ise çoğunlukla Facebook'ta aktiftir. Ancak her ii örgütte sosyal medyayı etkin kullanmak için çaba harcamaktadır. Çalışma hayatı ile ilgili hak kayıplarının önlenmesine yönelik kamuoyunun dikkatini çekecek görseller ile kampanyalar yapan bu örgütler, sosyal medya hesaplarını birer propaganda aracı olarak kullanmaktadırlar. CGT ve DGB kendi ülkelerindeki kampanyalara ek olarak son dönemde Covid-19'un yarattığ1 koşullardan kaynaklı \#VirtualMayDay etiketiyle 1 Mayıs etkinliklerinin online yapılması için destek vermiştir.

2 Çalışmanın yapıldığı dönemde Twitter'da DGB'nin Twitter'da 47.700 CGT'nin 23.500 takipçisi, Facebook'ta DGB'nin 30.800 CGT'nin 72.400 takipçisi bulunmaktadır. 
Ülkemizde ise en çok üyeye sahip üç konfederasyon, Türkiye İşçi Sendikaları Konfederasyonu (TÜRK-İŞ), Hak İşçi Sendikaları Konfederasyonu (HAK-İŞ) ve Devrimci İşçi Sendikaları Konfederasyonu (DİSK) sosyal medyayı görece etkin kullanmaya çalışmaktadırlar. Özellikle son yıllarda sosyal medyaya olan ilgisini artıran bu örgütler, en popüler sosyal medya platformlarında paylaşımlar yapmaktadır.

TÜRK-İŞ sosyal medya kullanımında Twitter ve Facebook'a dengeli bir ağırlık vermektedir. Twitter'da yaklaşık 23 bin, Facebook'ta yaklaşık 40 bin takipçisi bulunmaktadır. Örgüt sosyal medyada çok aktif olmamakla birlikte güncel gelişmelere paralel, işçileri bilgilendirici ve duyuru niteliğinde paylaşım yapmaktadır. Bu bağlamda TÜRK-İŞ sosyal medyayı genellikle iletişim faaliyeti için kullanmaktadır. Paylaşımlarında etiket kullanımına da ağırlık vermeyen TÜRK-İŞ, sosyal medyayı kampanya yürütme, propaganda yapma, kamuoyu oluşturma ve örgütlenme vb. amaçlarla kullanmamaktadır. Sadece bazı önemli günlerde sosyal medya paylaşımlarını değiştiren örgüt, 1 Mayıs etkinlikleriyle ilgili \#1MayısEmekveDayanısmaGünü, \#1Mayıs2020 etiketlerini kullanarak paylaşımlar yapmıştır. Üye sayısıyla kıyaslandığında bir milyondan fazla üyeye sahip TÜRK-İş'in hem Twitter'da hem de Facebook'da oldukça düşük takipçi sayısına sahip olduğu görülmektedir. Bununla beraber TÜRK-İŞ'in Twitter hesabında son 3 ayda yaptığı paylaşımlar dikkate alındığında günlük ortalama Tweet sayısı 0.45 olmaktadır. Örgütün günlük paylaşım ortalaması 1'in altıda kalmıştır. Dolayısıyla TÜRK-İŞ'in Twitter'da paylaşım sıklığı da düşüktür.

HAK-İŞ sosyal medyada Twitter ve Facebook hesaplarını tamamen senkronize kullanmaktadır. Twitter' da yaklaşık 16 bin, Facebook'ta ise yaklaşı 32 bin takipçisi bulunan örgütün Facebook ve Twitter'da yaptığı paylaşımlar birbirinin aynısıdır. Ancak farklı sosyal medya platformları, farklı içerik ve dillere ihtiyaç duymaktadır. Bu nedenle, HAK-İŞ'in, tüm platformlarda birebir aynı paylaşımları yapması örgütün sosyal medyada etkin bir profil oluşturmasını engellemektedir. Tüm platformlarda aynı paylaşımlar yapıldı̆̆ı için Twitter'da günlük ortalama paylaşım sayısı TÜRK-İŞ'e kıyasla yüksektir. Son 3 aylık paylaşımlara göre HAK-İ̧̧'in günlük ortalama Tweet sayısı 2.46' dır. TÜRK-İŞ ve DİSK ile kıyaslandığında sosyal medyada aktif bir profil sergileyemeyen HAK-İ̧̧'in sosyal medyayı sendikal faaliyetlerde kullandığını söylemek oldukça güçtür. Sendikanın sosyal medya hesaplarından çoğunlukla sendika ile ilgili haberler paylaşılmakta, işçilerle etkileşim düşük düzeyde kalmaktadır. 
HAK-İŞ'in sosyal medyayı kısmen de olsa bir kitle iletişim aracı gibi kullandığı söylenebilir. Bu bağlamda örgüt sosyal medyada çoğunlukla haber niteliği taşıyan paylaşımlara yer vermektedir. Bunu dışında herhangi bir sendikal faaliyette sosyal medya etkin olarak kullanmamaktadır.

DİSK, TÜRK-İŞ ve HAK-İŞ’e kıyasla sosyal medyayı çok daha aktif ve etkin kullanmaktadır. Örgütün son 3 aylık paylaşımları dikkate alındığında Twitter'da günlük ortalama paylaşım miktarı 14.6 olmaktadır. Bu oran TÜRKİŞ ve HAK-İ̧̧'e kıyasla oldukça yüksektir. Sosyal medyada ağırlığını Twitter ve Facebook'a veren örgüt hem çalışma hayatı hem de güncel sorunlarla ilgili paylaşımlar yapmaktadır. Twitter'da yaklaşık 100 bin, Facebook'ta ise yaklaşık 29 bin takipçisi olan DİSK, farklı etiketler kullanarak etkileşim düzeyini en üst seviyeye çıkarmaya çalışmaktadır. Sosyal medyayı iletişim, propaganda, örgütlenme ve kamuoyu oluşturma faaliyetleri için bir araç olarak kullanmaktadır. Aynı zamanda DİSK'e bağlı olarak çalışan Disk Araştırma Merkezi (DİSKAR), çalışma hayatını doğrudan ilgilendiren araştırma sonuçlarını@disk_ araştırma hesabından düzenli olarak paylaşmaktadır. Çoğunlukla yoğun propaganda ve örgütlenme çalışması yapmakta, güncel gelişmelere paralel olacak biçimde kamuoyu oluşturmak için çaba harcamaktadır. Örneğin, her ay meydana gelen iş kazası sayısını düzenli olarak paylaşan DİSK, iş kazalarını ve buna dair çözüm önerilerini sürekli gündemde tutmaktadır. Benzer biçimde açlık ve yoksulluk sınırı hesaplamaları, enflasyon sorunu ve işsizlik gibi paylaşımları sık sık ve güncel olarak yapmaktadır. Son dönemde Covid-19 nedeniyle çalışma hayatında ortaya çıkan hak kayıplarına dikkat çeken örgüt, ITUC ve ETUC'un başlattığı online kampanyaları desteklemektedir. Covid-19 nedeniyle geleneksel biçimde yapılamayan 1 Mayıs etkinliklerini de ilk defa sosyal medya üzerinden yapan DİSK, \#VirtualMayDay, \#Yaşasın1Mayıs ve \#1Mayıs etiketleriyle 1 Mayıs 2020 günü Türkiye'de ilk defa sosyal medya aracılığı ile "online eylem” gerçekleştiren işçi örgütü olmuştur.

Her ne kadar gerek uluslararası sendikalar gerekse ulusal sendikalar son yıllarda sosyal medya kullanıma önem vermeye başlasalar da sendikaların sosyal medya kullanımının işçiler tarafından nasıl algılandığı ile ilgili olarak yapılan çalışma sayısı oldukça sınırlıdır. Literatürde genellikle sosyal medyanın sendikalara etkileri ele alınmakta, olası sonuçları değerlendirilmektedir. Sendika üyesi işçilerin, sendikaların sosyal medya kullanımını nasıl gördüğü, neler beklediği ve işçiler için sendika söz konusu olduğunda sosyal medyanın ne 
ifade ettiği literatürde henüz yeni tartışılmaktadır (Panagiotopoulos 2012, s. 179-180). Bu bağlamda çalışma "işçilerin bakış açısından" sendikaların sosyal medya kullanımının hangi aşamada olduğunu ortaya koyması bakımından literatürde önemli bir boşluğu doldurmaktadır. Bursa ve Kırklareli illerinde sendikalı işçilerle yapılan derinlemesine görüşmeler 1şığında, işçilerin sendikaların sosyal medya kullanımını nasıl algıladığı, neler beklediği ve bu çerçevede sosyal medyanın işçiler için ne ifade ettiği tespit edilmeye çalışılmıştır.

\section{Araştırma}

\section{Araştırmanın Amacı}

Araştırmanın temel amacı sendikalı işçilerin, sendikaların sosyal medya kullanımına bakış açılarını tespit etmektir. Bu temel amaç çerçevesinde işçilerin; sendikaların sosyal medya kullanımına yönelik görüşleri konunun farklı boyutları açısından ele alınmaya çalışılmıştır. Bu bağlamda elde edilen bulgular, altı temel başlık altında toplanmıştır. Araştırmanın temel amacı doğrultusunda ve bu başlıklar altında elde edilen bulgular değerlendirilmiştir.

\section{Araştırmanın Yöntemi}

Çalışma kapsamında, 2019 yılında Bursa ve Kırklareli şehirlerinde farklı demografik özelliklere sahip, farklı sendikalara üye ve farklı sektörlerde (Sanayi, Hizmet, Gıda, Cam) çalışan 20 işçiyle3 (10 Bursa, 10 Kırklareli) yarı yapılandırılmış derinlemesine görüşme yöntemi kullanılarak görüşmeler gerçekleştirilmiştir. Görüşme yapılan işçiler aktif olarak sosyal medya kullanmakta ve sosyal medya platformları aracılığıyla en az bir sendikayı takip etmektedirler. Araştırma kapsamında Bursa ve Kırklareli şehirlerinin seçilmesinin temel nedeni bu iki şehrin farklı emek piyasası özellikleri taşımasıdır. Bursa emek piyasasında sanayi sektörünün ağırlığı hissediliyorken, Kırklareli'nde bu ağırlı̆̆ın tarım ve hizmet sektörüne geçtiği görülmektedir. Görüşmeler iş saatleri dışında işçilerin bulunduğu farklı mekânlarda yapılmıştır. Yapılan görüşmeler çerçevesinde toplam 22,5 saatlik görüşme kaydı, bu kayıtların çözümlenmesiyle yaklaşık 30 sayfalık veri elde edilmiştir. Çalışmada işçilerin talepleri doğrultusunda görüşme yapılan işçilerin isimlerine ve

3 Galvin tarafından yapılan araştırmada görüşme tekniğinde 12 görüşmeci optimum sayıdır. Galvin sayının 12 'den sonra arttırılmasının sonuçları etkilemeyeceğini matematiksel olarak belirtmiştir (Galvin, 2015). Bu nedenle görüşmeci sayısı iki farklı şehirde eşit olacak biçimde toplam 20 ile sınırlı tutulmuştur. 
sendikalarına yer verilmemiştir. Bunun yerine "Bursa, Gıda, Erkek, 34”, "Kırklareli, Hizmet, Kadın, 29” gibi işçilerin yaşadıkları şehirler, çalıştıkları sektörler, cinsiyetleri ve yaşları kullanılmıştır.

\section{Bulgular}

Çalışmada, görüşme yapılan işçilerden elde edilen bulgular; "Sosyal medyanın sendikalar açısından önemi ve gerekliliği, sosyal medya ve sendika güven ilişkisi, sendika ile iletişimde sendika web sayfast- sosyal medya tercihi, sendikaların sosyal medya paylaşımlarının yeterliliği, sosyal medyanın sendikal faaliyetlerde kullanım alanlarl, sendikal faaliyetlerde sosyal medya veya geleneksel yöntemlerin tek başına yeterliliği " altı başlıkta toplanmış, her alt başlıktaki bulgular diğer başlıklardaki bulgular ile ilişkili olacak biçimde değerlendirilmeye çalışılmıştır.

\section{Sosyal Medyanın Sendikalar Açısından Önemi ve Gerekliliği}

Görüşme yapılan işçilere: "Sosyal medya sendikalar açısından önemli midir? Sendikaların sosyal medya kullanmaları gerekli midir? Bu konuda ne düşünüyorsunuz?" sorusu sorulmuştur. Bu soruda işçilerin sosyal medya ile sendika arasında ilişkiyi nasıl algıladıkları, sendikalar açısından sosyal medyayı önemli ve gerekli görüp görmedikleri tespit edilmeye çalış1lmıştır. $\mathrm{Bu}$ sorulara görüşme yapılan işçilerin tümü sosyal medyanın sendikalar için önemli olduğu şeklinde yanıt vermişlerdir.

Bursa, Hizmet, Erkek, 38: "Sosyal medya günümüzde genel olarak çok önemli. Tabi sendikalar için de çok önemli. Insanlar her zaman bir araya gelemezler ama sosyal medya sayesinde kendileri gibi düşünen başka kişilerin de olduğunu görüp cesaretlenirler."

Kırklareli, Sanayi, Erkek, 44: “Haberleşme kaynağı. Sendika toplantılar yapıyor. Yaptıkları herhangi bir şeyi sosyal medya üzerinden paylaşırlarsa biz de üyeler olarak anlık görebiliyoruz. Sendikalar için gereklidir.”

Kırklareli, Hizmet, Kadın, 29: "Her şey sosyal medyadan paylaşıllyorken işçilerin hakları da daha detaylı olarak paylaşılabilir. Mesela benim sendikam var. Bir şey hakkında bilgi almak istediğim zaman insanlara her zaman ulaşamıyorum yoğun oluyorlar. Ama sosyal medya üzerinde bilgilendirilse ne zaman ihtiyacım olsa açar bakarım." 
Bursa, Sanayi, Erkek, 46: “Önemlidir, gereklidir. Sendika sosyal medya sayesinde sendikalı işçi ile sendikasız işçi arasındaki farkı gösterebilir. İşçilere ulaşabileceği ilk adım sosyal medyadır."

Kırklareli, Gıda, Kadın, 38: “Önemlidir. Mesela bir karar alındı̆̆ında duyurmak ve bizleri bilgilendirmek açısında önemlidir. Sosyal medya olmasa nerden haber alabiliriz ki?"

\section{Sosyal Medya, Sendika ve Güven İlişsisi}

Görüşme yapılan işçilere "Yarın uyandığınızda sendikanızın tüm sosyal medya hesaplarını kapattığını görürseniz, bu durum sendikanız için nasıl bir sonuç doğurur? Kendinizi nasıl hissedersiniz? Sendikaya duyduğunuz güvende değişiklik olur mu?" sorusu sorulmuştur.

Alınan yanıtlar doğrultusunda, görüşme yapılan işçilerin tümünün sosyal medya aracılığı ile sendikaya karşı ciddi bir güven inşa ettikleri görülmüştür. Nitekim görüşülen işçilerden bazıları sendikanın sosyal medya hesaplarını kapatması halinde sendikadan istifa etmeyi dâhi düşünebileceklerini belirtmişlerdir. Bu durum işçilerin sendikanın sosyal medya kullanımına ne kadar önem verdiklerini göstermesi açısından önem taşımaktadır. Bu doğrultuda; günümüzde sendikaya güvenin sağlanmasında sosyal medyanın ciddi bir öneme sahip olduğunu söylemek hatalı olmayacaktır.

Kırklareli, Sanayi, Erkek, 44: "İletişimimiz kopar hiçbir şeyi takip edemeyiz. Sendikamı değiştirmeyi bile düşünürüm çünkü iletişim sosyal medya üzerinden koparsa o iş olmaz. Sendikaya ulaşmaya çalışırız. Ne oluyor diye sorarı. Sendikanın sosyal medya hesaplarının olması bana güven verir.”

Bursa, Sanayi Erkek, 46: "Hüsran olur. Çünkü güvendiğim dağlara kar yağmış öyle diyeyim. Sendikanın sosyal medya hesaplarını olması güven açısından önemli. Benim sendikaya ulaşmam açısından iyi oluyor sosyal medya."

Kırklareli, Hizmet, Kadın, 34: “Çok çok kötü olur. Sendikayla en büyük bağımı şuan sosyal medya onu da kapatırsa sendikaya üye olduğumuzu bile unuturuz." 
Kırklareli, Cam, Erkek, 29: "Ylkım olur. Berbat bir şey olur. Sendika kapandı mı ne oldu başkan mı kaçtı ne oldu. Sonuçta her şeyi oradan takip ediyoruz. Güven azalması olur tabi ki neyi saklyyorlar ne yapıyorlar. Biz haber alamazsak deriz herkes yoluna yani."

Bursa, Gıda, Erkek, 29: "Sendikayı kapatmış gibi olurlar. Mesela bizim fabrikada ne kadar sendikaya üye olan kişi varsa hepsi sosyal medyadan takip ediyor sendikayı. Hatta sendikanın adresini bilmezler ama her gün sosyal medyadan takip ediyorlar. Güven sıfira iner."

Bursa, Hizmet, Erkek, 39: "Kötü bir durum olmaz olur mu ya! Sudan çıkmış balığa döneriz. Bütün her şeyi oradan takip ediyoruz. Aptal gibi oluruz. Sendikaya olan güvenim tabi ki sarsilır."

Kırklareli, Hizmet, Kadın, 29: "Biz onlara güveniyoruz oradan (sosyal medya hesaplarından) takip ediyoruz. Sendika bu hesapları kapatırsa güvendiğimiz dağlara kar yağar. Bir güven sorunu oluşur. Sendika bu konuda açıklama yapmazsa ilerde ayrılma kararı da alırım. Benim elimi bırakanın ben de elini burakırım.'

\section{Sendika ile İletişimde Sendika Web Sayfası - Sosyal Medya Tercihi}

Çalışmada, sendika - üye iletişiminde sendika web sayfası ile sosyal medyanın nasıl rol oynadığı, işçilerin sendika ile iletişimi sırasında sosyal medyayı ne ölçüde kullandıkları ve ona ne ölçüde önem verdikleri tespit edilmeye çalışılmıştır. Bu amaçla; görüşme yapılan işçilere; "Sendikayla ilgili bir haber almak istediğinizde ilk olarak sendikanın web sayfasına mı? Yoksa sosyal medya hesaplarına mı bakmayı tercih edersiniz?” şeklinde soru yöneltilmiştir.

İşçiler çoğunlukla sendika ile ilgili herhangi bir haber almak istediklerinde sosyal medyayı tercih ettiklerini dile getirmişlerdir. İşçilerin bir bölümü ise; her ne kadar ilk olarak sosyal medyayı tercih etseler de sosyal medyadaki bilgiyi sendikanın resmi web sayfasında teyit etme ihtiyacı duyduklarını belirtmişlerdir. Bunun temel nedeni sosyal medyadaki bilgi kirliliği olmuştur.

Kırklareli, Hizmet, Kadın, 31: "Facebook sayfasına girer bakarım. Her şey daha güncel ve bulması kolay oluyor. Telefondan hemen girebiliyorum.' 
Bursa, Hizmet, Erkek, 32: "Sosyal medya hesabina bakarım. Web sitesinde aradığım bir şeyi bulmak daha zor olur. Sosyal medyadan daha kısa sürede özet bilgiye ulaşabilirim."

Bursa, Sanayi, Erkek, 30: "Illk olarak sosyal medya hesaplarını incelemeyi tercih ederim. Çünkü sosyal medyada daha kısa, net ve açıklayıcı bilgiler, görseller var. Sosyal medyadan ögrendiğim bilgi önemliyse sendikanın web sayfasına da teyit etmek için bakarım. Bilgi kirliliği de olabilir sosyal medyada."

Kırklareli, Cam, Erkek, 29: "İkisine de giriyorum. Sosyal medyadan hep paylaşım yapılıyor. Daha çok sosyal medyayı takip ediyorum. Web sayfasına da giriyorum. Sosyal medyadan anlayamazsam web sayfasindan girip teyit ediyorum."

Kırklareli, Hizmet, Kadın, 29: “Web sayfasına bakarım çünkü Facebook'ta genelde çok yorum oluyor. Herkes farklı bir şeyler söylüyor. Maalesef Facebook'taki her şey doğru olmuyor."

Bursa, Sanayi, Erkek, 34: "Sendika Facebook'tan paylaşım yapıyor. Faydalı oluyor. Her zaman temsilcilere ulaşamıyoruz ama orayı takip ettiğimiz zaman sürekli bilgi alabiliyoruz."

Bursa, Hizmet, Erkek, 38: "Paylaşımları sosyal medyadan temsilci arkadaşlar yapıyor. Bu paylaşımlar faydalı oluyor. Mesela bayramlarda verilecek olan yardımlar ayakkabl, klyafet vs. ne zaman nerde verilecek oradan (sosyal medyadan) yaylnlaniyor herkesin haberi oluyor. Etkinlik olacaksa onun da duyurusu yapıliyor.”

\section{Sendikaların Sosyal Medya Paylaşımlarının Yeterliliği}

İşçilerin sendikaların sosyal medya paylaşımlarının yeterliliği konusundaki düşüncelerini belirlemek amacıyla: "Sendikanız üyelerine (size) haber ulaştırmak veya sizi bilgilendirmek için sosyal medyayı yeterli şekilde kullanıyor mu? Sorusu sorulmuştur.

Bu soruya görüşme yapılan işçiler farklı yanıtlar vermişlerdir. Bunun temel nedeni görüşme yapılan işçilerin farklı sektörlerde çalışmaları ve farklı sendikalara üye olmalarıdır. Bu çerçevede işçilerin bir kısmı sendikaların sosyal medya kullanımını yeterli bulmazken, bazı işçiler ise sendikaları bu konuda 
çok başarılı gördüklerini belirtmişlerdir. Bu durum Türkiye'de sendikaların sosyal medya kullanımı konusunda henüz belirli bir standarda sahip olmadığının, bazı sendikaların sosyal medyanın önemini henüz kavrayamadığının önemli bir göstergesi olarak kabul edilmiştir.

Kırklareli, Hizmet, Kadın, 29: "Sendikamız şu anda çok yeterli kullanmıyor sosyal medyayı. Çok paylaşım yapmıyor. Yeterli bilgilendirme yapılmıyor.”

Bursa, Sanayi, Erkek, 42: "Paylaşımlar yapılıyor ama çok da yeterli değil bence. Biraz daha fazla paylaşım yapsalar daha faydalı olur.”

Kırklareli, Cam, Erkek, 39: "Sendikamız sosyal medyayı aktif olarak kullanıyor. Bu çok faydalı bir şey. Sendika yaptı̆̆ı her şeyi paylaşıyor. Anında her şeyi yazıyor. Biz de bakıp öğreniyoruz."

\section{Sosyal Medyanın Sendikal Faaliyetlerde Kullanım Alanları}

Sosyal medyanın sendikalar açısından önemi; sosyal medyayı hangi sendikal faaliyetlerde kullanılabildikleri ile doğru orantılıdır. Bu çerçevede; görüşme yapılan işçilere: "Sizce sendikalar sosyal medyayı hangi sendikal faaliyette kullansa daha verimli olabilir? Örneğin; toplu pazarlık, grev, sendikal eğitim, örgütlenme vb.?" sorusu sorulmuştur. Burada temel amaç; sendikalı işçilerin sendikal faaliyetler söz konusu olduğunda sosyal medyaya ne gibi misyonlar yüklediğini tespit etmek ve sendikal faaliyetler söz konusu olduğunda işçilerin sosyal medya ile ilgili olarak ne düşündükleri ortaya çıkarmak olmuştur. Alınan cevaplar doğrultusunda işçiler öncelikle sendikadan bilgi edinme, sendikaya kolay ulaşabilme noktasında sosyal medyanın önemine değinmişler ancak sosyal medyanın imkân dâhilinde tüm sendikal faaliyetlerde kullanılması gerektiğini belirtmişlerdir.

Kırklareli, Sanayi, Erkek, 44: “......Haberleşme kaynağı. Sendika toplantılar yapıyor. Yaptıkları herhangi bir şeyi sosyal medya üzerinden paylaşırlarsa biz de üyeler olarak anlık görebiliyoruz.'

Kırklareli, Hizmet, Kadın, 29: '......Her şey sosyal medyadan paylaşıllyyorken iş̧̧ilerin hakları da daha detaylı olarak paylaşılabilir. Mesela benim sendikam var bir şey hakkında bilgi almak istediğim zaman insanlara her zaman ulaşamıyorum yoğun oluyorlar tatilde oluyorlar. Ama sosyal medya üzerinde bilgilendirilse ne zaman ihtiyacım olsa açar bakarım." 
Kırklareli, Gıda, Kadın, 38: “ ......Mesela bir karar alındı̆̆ında duyurmak ve bizleri bilgilendirmek açısında önemlidir. Sosyal medya olmasa nerden haber alabiliriz ki?"

Buna karşılık görüşme yapılan işçilerin üyelik süreci, toplu pazarlık, grev gibi sendikal faaliyetlerde sosyal medyanın kullanılması noktasında tereddütlü cevaplar verdikleri görülmüştür.

İşçilere "Sendikaya üye olma sürecinde sendikanın sizinle yüz yüze mi iletişime geçmesini tercih edersiniz, yoksa sosyal medya aracılığı ile mi? Tercihinizin nedenleri nedir?" şeklinde bir soru sorulmuştur.

Bu soruya görüşme yapılan işçilerin tümü örgütlenme ve üyelik çalışmalarında yüz yüze görüşmeyi tercih ettikleri sosyal medyadan kurulacak ilişkinin "samimi”" olduğuna inanmadıkları şeklinde yanıt vermişlerdir.

Bursa, Sanayi, Erkek, 25: "Yüz yüze daha iyi olur. En azından sendika görevlisinin gelmesi yüz yüze görüşmek daha iyi. Mesela Facebook üzerinden mesaj attı diyelim Ben şöyle algılarım; Bu insan beni ciddiye almıyor diye düşünebilirim."

Bursa, Hizmet, Erkek, 32: “Ben yüz yüze iletişime geçmesini isterim. Çünkü soracağım sorulara birebir cevap almak isterim. Karşı tarafin hali tavrı da güven vermesi açısından önemli. Burada sosyal medya tamamlayıcı olabilir."

Kırklareli, Hizmet, Kadın, 31: “Gelip yüz yüze konuşmak her zaman daha iyi. Biz sendikaya üye olurken sendikadan gelip kendilerini tantttılar. Biz de sosyal medyadan baktık hangisi nedir neler yapmış bugüne kadar ne hak almışlar araştırdık ona göre karar verdik. Ama ilk tanışmanın yüz yüze olması her zaman daha önemli."

Kırklareli, Sanayi, Erkek, 44: "Yüz yüze görüşme akılda daha fazla kalıcı olur. Bazı şeyler yüz yüze görüş̧mek daha faydalıdır. Soru sorabilirsin. Mesajla bir yere kadar. Üyelikte yüz yüze görüşmek daha iyi."

Toplu pazarlık sürecinde sendikaların sosyal medyadan yararlanmaları konusunda görüşmeye katılan işçiler farklı görüşlere sahiptir. İşçilere "Toplu sözleşme taslaklarının hazırlanması, sözleşme maddelerinin tartışılması gibi süreçlerin sosyal medya üzerinden tartışılması sizce faydalı olur mu?" sorusu sorulmuştur. Bazı işçiler sosyal medyanın toplu sözleşme sürecinde 
faydalı olacağını düşünürken, bazı işçiler bu durumun kötüye kullanılabileceği görüşündedir.

Bursa, Sanayi, Erkek, 46: "Faydalı olur tabi. Yani toplu sözleşmeyle ilgili taslakları sendika kendi kapalı kutu içinde hazırlaması başka bir şey. Sosyal medyada paylaşılması çok daha iyi olur. Mesela sendikalı olmayan bir kişi bu taslaklara ulaşıp görse onun içinde iyi olur."

Bursa, Hizmet, Erkek, 38: "Faydall olur tabi ki. Herkese önceden haber verilmiş olur. Sendikanın şeffaf olduğunu gösterir. Şimdi bir sendika başkanının karşısına çıkıp "ya nasıl bir taslak hazırlamışsınız” diyemeyen işçiler sosyal medyadan daha rahat yorum yazabilir. Mesela "şu maddeyi unutmuşsunuz, bu maddeyi de eklesek daha iyi olmaz mi" gibi bir yorum yapabilir. Tabi herkesin muhalif olması gibi sorunlar da çıkabilir ortaya."

Kırklareli, Hizmet, Kadın, 31: “Çok iyi olur. Üst kesime mesela sendika başkanına rahat ulaşılamıyor. Ama bu şekilde olduğu zaman insanlar hiç olmazsa bir şeyler yazar, yorum yaparlar. Fikirlerini sunabilir."

Kırklareli, Hizmet, Erkek, 39: "Faydalı olur. En azından canlı yayında görürsün ne olur bittiğini. En azından ben de kendi düşüncelerimi yazarım. Bĕ̆enmedim veya beğendim."

Bursa, Sanayi, Erkek, 34: “Önceden biz sendikaya gidiyorduk orda bize anlatıyorlardı. Sosyal medyadan paylaşılmasının faydası da olur zararı da olur. Mesela biri yorum yazar daha sonra başka biri farklı bir şey yazar olay büyüyebilir. Amacından çıkabilir."

Bursa, Hizmet, Erkek, 32: "Çok demokratik gibi görünse de kendi içinde bilgi kirliliği barındıracak bir süreç olur. Çok sağlıklı olacağını düşünmüyorum. Gerekli önlemler bu işin uzmanları tarafindan alınmadığı sürece gelişi güzel şekilde yapılması doğru olmaz."

Sendikal eğitimlerin sosyal medya üzerinden verilmesi konusunda işçilere yöneltilen "Sendikal eğitimlerde sosyal medyanın etkin olarak kullanılmasını faydalı buluyor musunuz?” sorusuna işçilerin yaklaşımı negatif yönlü olmuştur. Eğitim söz konusu olduğunda işçilerin büyük bir çoğunluğu sosyal medya yerine yüz yüze eğitimin daha faydalı olacağını düşünmektedir. 
Bursa, Sanayi, Erkek, 46: “...Verilecek eğitim sosyal medyada ikna edici olmaz. Sosyal medyadan faydalı olmaz. Ë̆itim birebir olmalı."

Kırklareli, Cam, Erkek, 29: "Sendikal eğitimler yüz yüze olmalı. Sosyal medyadan verilen eğitim sağglklı olmaz."

Kırklareli, Gıda, Kadın, 30: “Çok etkili olmaz. Çünkü insanlar vakit ayırmaz öyle olursa. Eğitimler birebir olursa daha iyi olur.”

Bursa, Gıda, Erkek, 26: "Yüz yüze iletişimin daha sağlıklı olacă̆ını düşünüyorum. Çünkü sosyal medya iletişimin kolaylaşması açısından iyi bir alan ama işçinin aklındaki soruyu sorması, derdini daha iyi anlatabilmesi için yüz yüze iletişim gereklidir.”

\section{Sendikal Faaliyetlerde Sosyal Medya veya Geleneksel Yöntemlerin Tek Başına Yeterliliği}

Görüşme yapılan işçilere "Sendikalar faaliyetler sadece sosyal medya veya sadece geleneksel yöntemlerle yürütülebilir mi? Bu konuda ne düşünüyorsunuz?" şeklinde bir soru yöneltilmiştir.

Görüşme yapılan işçiler sendikal faaliyetlerin sadece sosyal medya veya sadece geleneksel yöntemlerle yürütülmesi konusuna olumlu bakmamışlardır. Görüşmeye katılan işçilerin tümü sosyal medyanın sendikal faaliyetlerde “tamamlayıcı" bir rolü olması gerektiğini, günümüzde artık sosyal medyasız sendikal faaliyetlerin yapılamayacağını ancak sadece sosyal medya üzerinden de sendikal faaliyetlerin tek başına yürütülemeyeceğini, sosyal medya ile geleneksel yöntemlerin birbirlerini tamamlaması gerektiğini belirtmişlerdir.

Kırklareli, Sanayi, Erkek, 41: "Sendikalar faaliyetler sosyal medya üzerinde yapılabilir ama sadece sosyal medya üzerinden bir şeyler yapmak yeterli değildir. Eski yöntemleri de biraz beslemek gerekiyor. Davullu zurnal şeyleri de yapmak lazım (grev ve eylemleri işaret ediyor)"

Bursa, Sanayi, Erkek, 46: "Sadece sosyal medyadan yürütülemez. İkna edici olmaz. Eski yöntemler biraz gerekli. İkisini birlikte götürmek de olur ama eski yöntemler daha ikna edici olur.” 
Kırklareli, Hizmet, Kadın, 29: "Her ikisini de kapsamalı. Sadece sosyal medya olması yeterli olmaz. Önce yüz yüze olur daha sonra bunu yaygınlaştırmak amaçlı sosyal medyayı da kullanabilir."

Bursa, Hizmet, Erkek, 38: "Sosyal medya üzerinden sadece sesini duyurur sendika. Fiili bir eylem olmaz sosyal medya üzerinden. Sahada olmak gerekir. Günümüzde sadece geleneksel yöntemlerle de olmaz. Sosyal medya olmazsa haberimiz olmaz. Beraber olmalılar.”

\section{Değerlendirme ve Sonuç}

Yaşadığımız çağın reddedilemez bir gerçekliği olan internet ve sosyal medya teknolojileri, büyük bir hızla günlük hayatımızın parçası haline gelmektedir. $\mathrm{Bu}$ durum gerek çalışma hayatını gerekse bir bütün olarak toplumsal hayatı keskin bir dönüşüme zorlamaktadır. Bugün sosyal medya, milyonlarca insanın her gün kullandığı bir teknoloji olarak sadece iletişim ve eğlence ağı olmanın ötesine çoktan geçmiştir.

Halen sosyal medya sadece bireylerin değil, örgütlerin de çeşitli amaçlarla kullandığı işlevsel bir araç haline gelmiştir. Akıllı cep telefonlarının ve mobil internet ağlarının yaygınlaşmasına paralel olarak sosyal medya platformları toplumun bütününde olduğu gibi işçiler arasında da hıla popülerlik kazanmaktadır. Bu doğrultuda günümüzde sendikalar gerek kendi üyelerine ve tüm işçilere, gerekse toplumun bütününe ulaşabilmek için artık sosyal medya araçlarını etkin biçimde kullanmak durumundadırlar.

Son yıllarda uluslararası sendikalar ve sınırlı sayıda gelişmiş ülkede ulusal sendikaların faaliyetlerinde giderek artan şekilde sosyal medyadan yararlandıkları görülmektedir. Ancak bu konuda henüz büyük bir ilerleme sağlandığını söylemek mümkün değildir. Benzer şeklide Türkiye'de de sendikaların sosyal medya kullanımı konfederasyon ve işkolu sendikaları düzeyinde henüz emekleme aşamasındadır.

Sendikaların faaliyetlerinde sosyal medyadan yararlanmaları tamamen sorunsuz olmasa da sendikalar açısından birçok olumlu sonucu beraberinde getirmektedir. Günümüzde bilimsel çalışmalar büyük ölçüde sendikaların sosyal medya kullanımını sendikaların bakış açısı ile ele almaktadır. Buna karşılık sendikaların sosyal medya kullanımına işçilerin bakış açısı bilimsel düzeyde henüz yeterince ele alınmamıştır. 
Bu çalışmada konunun bu boyutu üzerine yoğunlaşılmaya çalışılmış Bursa ve Kırklareli şehirlerinde farklı demografik özelliklere sahip, farklı sendikalara üye 20 işçiyle yarı yapılandırılmış derinlemesine görüşme yöntemi kullanılarak bir alan araştırması yapılmıştır. Bu alan araştırması sonucunda konu ile ilgili olarak görüşme yapılan işçilerden aşağıda yer alan dört çarpıcı bulgu elde edilmiştir:

1) Görüşme yapılan tüm işçiler sosyal medyanın günümüzde sendikalar açısından önemli bir araç olduğu konusunda hemfikirdir. İşçiler bunun nedenin çoğunlukla "sendikayla olan iletişimin" kolaylığı ile açıklamışlardır. Buna ek olarak işçilerin verdiği yanıtlar, sendikanın sosyal medyada var olmasının işçilere bir şekilde güven verdiği yönündedir.

2) İşçilerin verdiği cevaplar doğrultusunda sendikaya duyulan güven ile sosyal medya arasında çok güçlü bir ilişki olduğu görülmüştür. Zira görüşmeye katılan işçiler sosyal medyayı etkin kullanan sendikaları işçiler açısından daha şeffaf ve daha güvenilir olarak görmektedirler. Dolayısıyla; sosyal medya, güven tazelemek ve şeffaflığın sağlanması açısından sendikalar için güçlü bir araç olarak görülmelidir. Buna göre; ancak etkin ve aktif bir sosyal medya kullanımı ile sendikalar mevcut konumlarını iyileştirme şansını elde edebileceklerdir.

3) Sosyal medya, görüşmeye katılan işçiler tarafindan işçilerin sendikaya ulaşılabilecekleri en kısa ve en hızlı yol olarak görülmektedir. Bu durum sendikalar için işçilere temas edebilmek açısından bir firsat oluşturmaktadır. Görüşmeye katılan işçiler üyesi oldukları sendikanın sosyal medya hesaplarını günlük incelediklerini, sendikayla ilgili duyuru, bilgilendirme gibi anlık haberleri sosyal medyadan aldıklarını belirtmişlerdir. Bu noktada sendikanın dikkat etmesi gereken en önemli faktör sosyal medyada hızla yayılan bilgi kirliliğinden uzak durabilmektir. Dolayısıyla sendikalar sosyal medyadaki paylaşımlarında olabildiğince net ve açık olmalıdırlar.

4) Her ne kadar görüşmeye katılan işçiler sosyal medyayı sendikaya ulaşabilecekleri en kolay yol olarak belirtseler de birçok sendikal faaliyetler açısından birebir teması hâla en etkin yöntem olarak görmektedirler. Özellikle örgütlenme ve yeni üyelik süreçlerinde yüz yüze iletişimin önemi görüşmeye katılan işçiler tarafından özellikle vurgulanmıştır. 
5) Görüşmeye katılan işçilere göre; sendikal faaliyetlerde geleneksel yöntemler ile sosyal medya birlikte yürütülmeli, sosyal medya geleneksel faaliyetleri tamamlayıcı bir rol üstlenmelidir.

Farklı şehirlerde yapılan bu çalışmanın il bazında karşıllaştırmasına bakıldığında, Bursa ve Kırklareli'nde işçilerin bazı temel noktalarda ortak beklentiler içinde oldukları tespit edilmiştir. Örneğin sendikaların sosyal medya kullanımı ile sendikalara duyulan güven arasındaki ilişki bakımından il fark etmeksizin işçilerin ortak beklentiler içinde olduğu görülmektedir. Benzer biçimde sendikal şeffaflık açısından sosyal medyanın önemi de Bursa ve Kırklareli’ndeki işçilerin ortaklaştığı beklentiler arasındadır. Bununla birlikte sendikayla kurulacak iletişimde sosyal medyanın önemi noktasında iller arasında farklılıklar ortaya çıkmaktadır. Bursa' da görüşme yapılan işçiler, sendikayla kurulacak iletişimde sosyal medyanın güçlü bir araç olarak kullanılabileceğini belirtirken; Kırklareli’nde görüşme yapılan işçiler, sendikayla kurulacak iletişimde ağırlığın geleneksel yollarlar (fabrika ziyaretleri, toplantılar vb.) olması gerektiğini vurgulamışlardır. Bu durumun iller arasındaki ölçek ve sektör farklılığından kaynaklanması muhtemeldir. Bursa' da emek piyasası sanayi ağırlıklı ve çok sayıda farklı işçiden oluşuyorken, Kırklareli emek piyasası nicel bakımdan çok daha küçük, hizmet ve gıda ağırlıklı bir yapıya sahiptir. Bu farklılık, il bazlı bakıldığında işçiler arasında sendikayla kurulacak iletişimin biçimi tercihinde de kendini gösterebilmektedir.

Görüşmelerden elde edilen bulgular göstermektedir ki; sosyal medya birçok açıdan sendikalar için bir firsattır. Sosyal medya işçiler açısından sendikayı hissedebildikleri bir alandır. Sendika işçilere birebir temas etmese de sosyal medyadan yapacağı paylaşımlarla işçilerle arasındaki bağı güçlendirebilir. $\mathrm{Bu}$ nedenle önümüzdeki yıllarda aktif ve etkin biçimde sosyal medya kullanmadan sendikacılık yapmak daha da zorlaşacaktır. Sosyal medyanın hızla önem kazanması, bu alanın giderek karmaşıklaşmasına ve yönetiminin zorlaşmasına neden olmuştur. Bu bağlamda sendikalar sosyal medya kullanımına özen göstererek, daha organize ve profesyonel bir sosyal medya yönetimi gerçekleştirmelidir. Sosyal medya yönetimi, asıl işi bu olmayan kişilerce değil, bu işte uzman profesyoneller tarafından yapılmalıdır. Aksi halde özellikle orta ve uzun vadede sendikaları sosyal medya açısından çok daha büyük sorunlar beklemektedir. 
Görüşme yapılan işçiler, il ve sektör farkından bağımsız olarak sendikal şeffaflık, güven, iletişim, sendikal faaliyetler vb. birçok konuda sosyal medyanın önemine vurgu yapmışlardır. Ancak, sosyal medyanın sendikalar için önemi vurgulanırken çok dikkat edilmesi gereken bir "sınır" bulunmaktadır. Bu sınır; sosyal medyanın sendikalar için bir amaç değil, sendikaların temel hedeflerine ulaşmak için kullanacakları bir araç olduğudur. Bir diğer ifadeyle, sosyal medya sendikalar için "sihirli bir değnek" olarak kabul edilememelidir.

Sınıf ve çıkar örgütleri olan sendikalar, işçilerin hak ve çıkarlarını temel sendikal faaliyetlerle savunurken, sosyal medyayı tamamlayıcı ve işlevsel bir araç olarak görmeli ve buna uygun hareket etmelidir. Aksi halde sosyal medyanın araç olmaktan çıkarak bir amaç haline dönüşmesi, sendikanın sınıfsal zemininden kopmasına ve sonuç olarak temel sendikal faaliyetlerini yerine getirememesine neden olacaktır.

Hakem Değerlendirmesi: Dış bağımsız.

Çıkar Çatışması: Yazarlar çıkar çatışması bildirmemiştir.

Finansal Destek: Yazarlar bu çalışma için finansal destek almadığını beyan etmiştir.

Peer-review: Externally peer-reviewed.

Conflict of Interest: The authors has no conflict of interest to declare.

Grant Support: The authors declared that this study has received no financial support. 


\section{Kaynakça/References}

Almagor, R. C. (2011). Internet History. International Journal of Technoethics, 2(2), 45 64. https://doi.org/10.4018/jte.2011040104

Atabek, Ü. \& Yücesan Özdemir, G. \& Yüce, E. (2011). Siberuzayda Sendikalar: Yeni Olanaklar, Yeni Sorunlar. XI. Türkiye'de Internet Konferansı. 21-26 Aralık 2006. TOBB Ekonomik ve Teknoloji Üniversitesi, Ankara. Retrieved From http://inet-tr.org. tr/inetconf11/

Colgan, F. \& Ledwith, S. (2003). Gender, Diversity and Trade Unions International Perspectives. New York, NY: Routledge.

Djik, J. V. (2016). Ă̆ Toplumu, (Ö. Sakin, Çev.). İstanbul: Epsilon Yayıncılık.

Fuchs, C. (2015). Dijital Emek ve Karl Marx, (E. Tahir ve S. Oğuz, Çev.). Ankara: Notabene Yayınları.

Fuchs, C. (2016). Sosyal Medya Eleştirel Bir Giriş, (İ. Kalaycı ve D. Saraçoğlu, Çev.). Ankara: Notabene Yayınları.

Galvin, R. (2015). How many interviews are enough? Do qualitative interviews in building energy consumption research produce reliable knowledge? Journal of Building Engineering, 1, 2-12. https://doi.org/10.1016/j.jobe.2014.12.001

Gauntlett, D. (2011). Making Is Connecting: The Social Meaning of Creativity, From DIY and Knitting to Youtube and Web 2.0, Cambridge: Polity Press.

Gerbaudo, P. (2012). Tweets and the Streets Social Media and Contemporary Activism, London, UK: Pluto Press.

Guppta, K. (2016, 12 Ekim). Will Labor Unions Survive In The Era Of Automation?, Forbes. Erişim Adresi: https://www.Forbes.com

Hodder, A. \& Houghton, D. (2015). Union Use of Social Media: A Study of the University and College Union on Twitter. New Technology, Work and Employment, 30(3), 173189. http://dx.doi.org/10.1111/ntwe. 12055

ICAAN (2020, 12 Haziran). Domain Name Registration Data Lookup. Retrieved from https://lookup.icann.org/

Krasenkiene, A., Kazokiene, L. \& Susniene D. (2014), Relationships of the Trade Unions with the Media: The Lithuanian Case. Administrative Sciences - Open Access Journal, 4(1), 1-14. https://doi:10.3390/admsci4010001

Lasswell, H. (1938). Techniques in the World War, New York, NY: Peter Smith.

Lee, E. (2008, 12 Şubat). How The Internet Makes Union Organizing Harder [Web log post]. Retrieved from http://www.ericlee.info/2008/02/how_the_internet_makes union_o.html

Lucio, M. M. (2003). New Communication Systems And Trade Union Politics: A Case Study of Spanish Trade Unions and The Role of The Internet. Industrial Relations Journal, 34(4), 334-346. https://DOI:10.1111/1468-2338.00279

McQuail, D. (2009). Mass Communication Theory, London, UK: SAGE Publications. 
Nicita, A. \& Rizzolli, M. (2009). The Case For The Vitrual Strike, Portuguese Economic Journal, 8(3), 141-160. https://doi.org/10.1007/s10258-009-0044-X

O'Reilly, T. (2005, 30 Eylül). What Is Web 2.0 Design Patterns and Business Models for the Next Generation of Software. Retrieved from https:/www.oreilly.com/pub/a/ web2/archive/what-is-web-20.html

Panagiotopoulos, P. \& Barnett, J. (2015). Social Media in Union Communications: an International Study with UNI Global Union Affiliates. British Journal of Industrial Relations, 53(3), 508-532. https://DOI:10.1111/bjir.12060

Panagiotopoulos, P. (2012). Towards Unions 2.0: Rethinking the Audience of Social Media Engagement. New Technology, Work and Employment, 27, 178-192. https://DOI:10.1111/j.1468-005X.2012.00287.x

Parry, S. (2013, 13 Mart). Union Apps. Retrieved from http:/www.infobo.com/tradeunion-apps/

Pearce, K. J. (2009). Encyclopedia of Communication Theory. In: Stephen W. Littlejohn \& Karen A. Foss (Eds.), Media and Mass Communication Theories (pp. 624-627) Ed, California, CA: SAGE Publications.

Regov, R., Sprenger, W., Kirov, V.,Thomson, G. \& Nunzio, D. D. (2016). The Use Of New ICTs in Trade Union Protests - Five European Cases, Transfer: European Review of Labour and Research, 22(3), 215-329. https://doi.org/10.1177/1024258916655761

Selamoğlu, A. \& Özsoy, A. (2008). Türkiye'de İşçi Sendikalarının ve Konfederasyonların Web Siteleri İçerik Analizi Üzerine Bir Değerlendirme, Çalışma ve Toplum, 16(1), 31-60.

Sevgi, H. (2019). Sosyal Medya ve Sendikalar. IŞ, GÜÇ Endüstri Ilişkileri ve İnsan Kaynakları Dergisi, 21(1), 57-72. https://DOI.org/10.4026/isguc.543452

Tokol, A. (2019). Endüstri İlişkileri ve Yeni Gelişmeler (8.bs.). Bursa: Dora Yayınevi.

Yılmaz Sert, N. (2015). Sendikalarda Yeni İletişim Teknolojilerinin Kullanımı ve Örgütsel İletişim Faaliyetlerine Etkisi. Selçuk İletişim, 8(4), 104-130. Retrieved from https://dergipark.org.tr/tr/pub/josc/issue/19030/201102 